\title{
Krūties naviko metastazių išplitimas centrinẻje nervų sistemoje. Klinikinis atvejis ir literatūros apžvalga
}

\author{
I. Radzevičiūtè* \\ R. Pačinskaité* \\ R. Gleizniené** \\ *Lietuvos sveikatos mokslu \\ universitetas, Medicinos akademija, \\ Medicinos fakultetas \\ **Lietuvos sveikatos mokslu \\ universitetas, Medicinos \\ akademija, Radiologijos klinika
}

\begin{abstract}
Santrauka. Krūties vėžys yra labiausiai paplitusi moterų onkologinė liga visame pasaulyje. Pirmosios atokiosios metastazès dažniausiai aptinkamos plaučiuose, galvos smegenyse, kauluose, kepenyse. Metastazinio krūties vèžio simptomai labiausiai priklauso nuo išplitimo vietos. Metastazės galvos smegenyse, priklausomai nuo jų lokalizacijos, gali sukelti tokius simptomus kaip pykinimas, galvos skausmas, hemiparezè, regejjimo sutrikimai, traukuliai, neaiški kalba, mąstymo sutrikimai, galvos svaigimas. Krūties vėžio metastazès smegenyse dažniausiai aptinkamos smegenėlèse ir pamato branduoliuose. Galimas ir intraventrikulinis, leptomeninginis plitimas centrinėje nervų sistemoje; nors tai yra reta krūties véžio metastazių lokalizacija, tačiau nurodanti agresyvią vėžio eigą. Jautriausias tyrimas, diagnozuojant metastazes smegenyse, yra magnetinio rezonanso tomografija. Šių lokalizacijų metastazèms gydyti dažniausiai pasirenkama chirurgija, stereotaksinė radiochirurgija ar visų smegenų radiacinè terapija. Šiame straipsnyje pristatomas krūties vėžiu sergančios $34 \mathrm{~m}$. moters, kuriai diagnozuotas ligos išplitimas ị centrinę nervų sistemą, klinikinis atvejis. Pacientei taikytas gydymas stereotaksinès radiochirurgijos centre „Sigulda“ Latvijoje; vẻliau nustatytas intraventrikulinis metastazių plitimas galvos smegenyse. Taip pat šiame straipsnyje apžvelgiama literatūra, susijusi su krūties vèžio metastazių pasireiškimu centrinèje nervų sistemoje, diagnostika ir gydymo rekomendacijomis.
\end{abstract}

Raktažodžiai: krūties vėžys, metastazès galvos smegenyse, magnetinio rezonanso tomografija, intraventrikulinis plitimas, leptomeninginis plitimas, stereotaksinė radiochirurgija.

\section{IVADAS}

Pasaulio sveikatos organizacijos duomenimis, $2018 \mathrm{~m}$. pasaulyje buvo užregistruota daugiau nei 2 milijonai naujų krūties véžio atvejų ir daugiau nei 600000 mirčių dèl jo [1]. Sergamumas krūties vėžiu pasaulyje sparčiai didèja: prognozuojama, kad $2040 \mathrm{~m}$. krūties vėžys bus nustatytas daugiau nei 3 milijonams moterų ir nulems beveik 1 milijoną mirčiu [2]. Lietuvoje $2018 \mathrm{~m}$. buvo užregistruoti 1742 nauji krūties vėžio atvejai, tai sudare net $21 \%$ visų naujų vèžio atvejų tarp moterų [3]. Tobulejjant tiek diagnostikos, tiek gydymo metodams, išgyvenamumas, sergant krūties vèžiu, didejja, tad vis dažiau susiduriama su pažengusios ligos požymiu - metastazèmis. Krūties vèžys yra linkęs plisti net ir ị atokiai esančius or-

\section{Adresas: \\ Ieva Radzevičiūtè \\ El.paštas iradze@gmail.com}

ganus. Dažniausiai pirmosios atokiosios metastazès aptinkamos kauluose, plaučiuose, kepenyse ir centrinèje nervų sistemoje (CNS) [4, 5]. CNS, kaip pirmųjų tolimųjų metastazių atsiradimo vieta, yra siejama su blogiausia ligos prognoze [5]. Retais atvejais galimas ir intraventrikulinis, leptomeninginis plitimas CNS, kuris yra labai agresyvus, nes dar labiau sutrumpina pacientų išgyvenamumą [6].

\section{ATVEJO ANALIZE}

$34 \mathrm{~m}$. pacientè kreipèsi į šeimos gydytoją dèl savityros metu užčiuopto sukietėjimo kairèje pažastyje. Papildomu skundų pacientẻ neturèjo. Atlikus krūtų ultragarsinị tyrimą, patologinių pokyčių nenustatyta.

Po metų atlikus mamografinị tyrimą, aptikti įtartini pakitimai kairëje krūtyje. Atlikta stulpelinė biopsija, jos rezultatas: infiltracinè duktalinè karcinoma, G2, ER - teigia-

(C) Neurologijos seminarai, 2020. Open Access. This article is distributed under the terms of the Creative Commons Attribution 4.0 International License CC-BY 4.0 (http://creativecommons.org/licenses/by/4.0/), which permits unrestricted use, distribution, and reproduction in any medium, provided you give appropriate credit to the original author(s) and the source, provide a link to the Creative Commons license, and indicate if changes were made. 

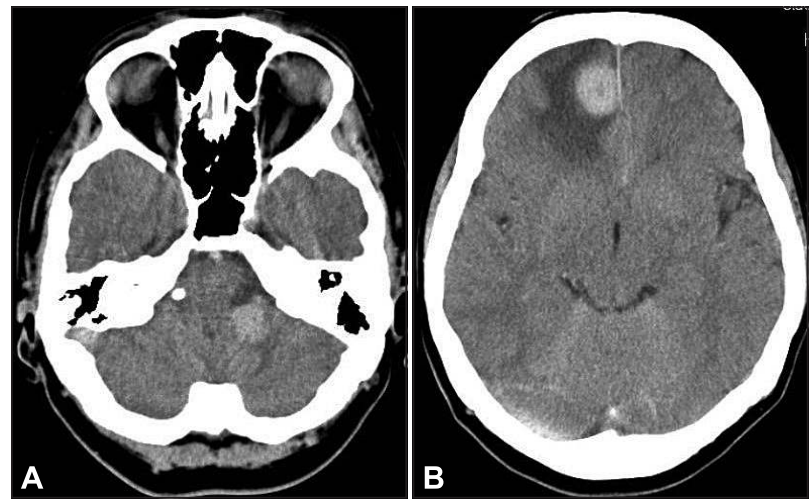

1 pav. KT vaizdai, aksialinė plokštuma (tyrimas atliktas LSMU KK Radiologijos klinikoje, 201611 10)

A: kairiajame smegenėlių pusrutulyje matomas $\mathrm{k} / \mathrm{m}$ kaupiantis židinys su nedidele perifokaline edemine reakcija; B: dešinėje frontaliai kortikosubkortikaliai analogiškas židinys su plačia perifokaline edemine reakcija

ma $(1 \times 5+2 \times 1+3 \times 5), P R-$ teigiama $(1 \times 5+2 \times 5+3 \times 1)$, HER2 - teigiama (3+). Krūtų magnetinio rezonanso tomografija (MRT) rodė kairès krūties daugiacentrị naviką $(120 \times 43 \times 80 \mathrm{~mm})$ su išplitimu ị pažasties limfmazgius. Tolimųų metastazių nestebèta. Dẻl pažengusio proceso gydymas pradètas nuo neoadjuvantinès chemoterapijos kursų. Praẻjus pusmečiui po ligos diagnozavimo, atlikta tausojamoji kairès krūties operacija, sarginio limfmazgio biopsija ir abiejų krūtų plastika.

Praejjus mėnesiui po operacijos, pacientė pradejo justi staigius trumpalaikius galvos svaigimo epizodus, galvos skausmą, temdavo akyse. Dėl šių skundų atliktas galvos smegenų kompiuterinès tomografijos (KT) tyrimas (1 pav., 201611 10).

KT vaizduose nustatytos metastazės dešinėje frontalinëje skiltyje ir kairiajame smegenėlių pusrutulyje. Metastazių buvimą CNS patvirtino ir galvos smegenų MRT (2 pav., 201611 19). Neuroonkologinių ligų multidisciplininio konsiliumo metu nutarta, kad tikslinga yra chirurginiu būdu pašalinti frontaliai esantị židinị ir taikyti radioterapiją kairiajame smegenèlių pusrutulyje esančiam dariniui. Pacientė siūlomo gydymo plano atsisakè ir nusprendè gydytis Latvijoje esančiame stereotaksinès radiochirurgi-
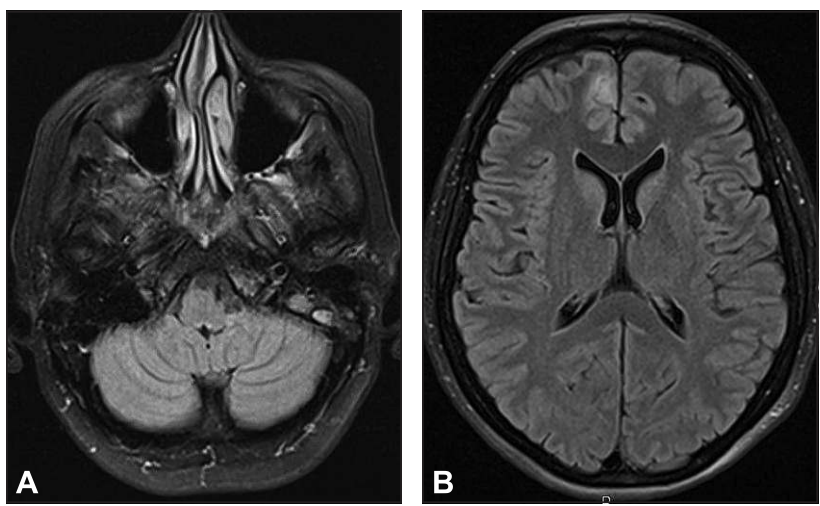
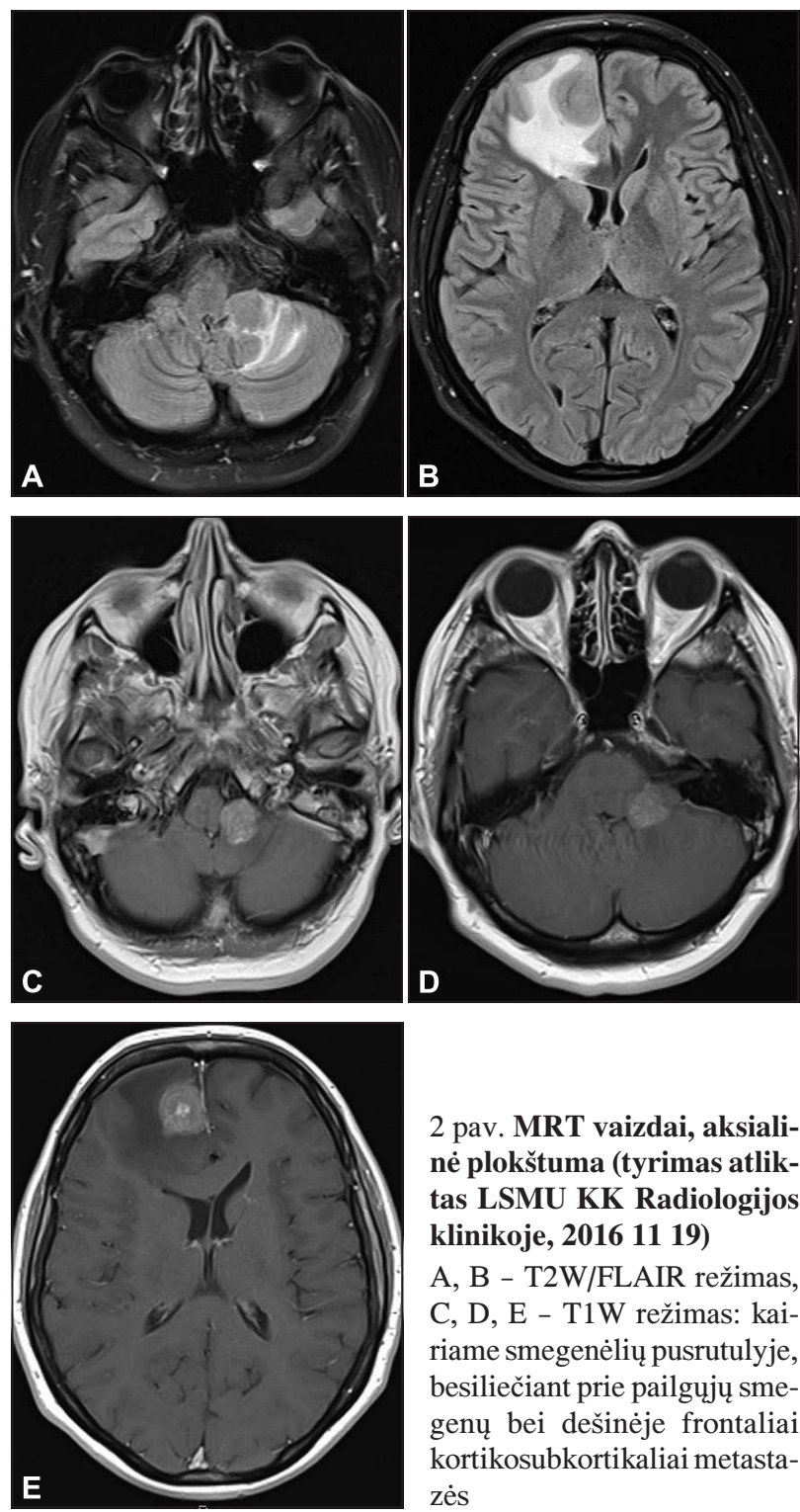

2 pav. MRT vaizdai, aksialinẻ plokštuma (tyrimas atliktas LSMU KK Radiologijos klinikoje, 201611 19)

A, B - T2W/FLAIR režimas, C, D, E - T1W režimas: kairiame smegenėlių pusrutulyje, besiliečiant prie pailgụjų smegenų bei dešinèje frontaliai kortikosubkortikaliai metastazès

jos centre „Sigulda“. Praẻjus dviem mėnesiams po gydymo minėtoje klinikoje, kontrolinės galvos smegenų MRT vaizduose (3 pav., 2017 02 24) stebima žymiai teigiama dinamika.
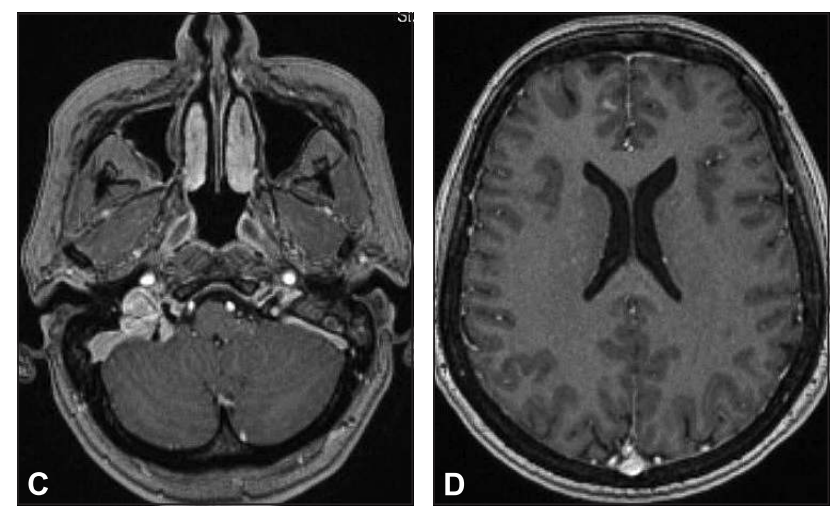

3 pav. MRT vaizdai, aksialinė plokštuma (tyrimas atliktas LSMU KK Radiologijos klinikoje, 201702 24)

A, B - T2W/FLAIR režimas, C, D - T1W režimas: po gydymo stereotaksinès radiologijos centre „Sigulda“ Latvijoje stebimi žymiai sumažèję židiniai kairèje užpakalineje dauboje ir dešinejje frontaliai 

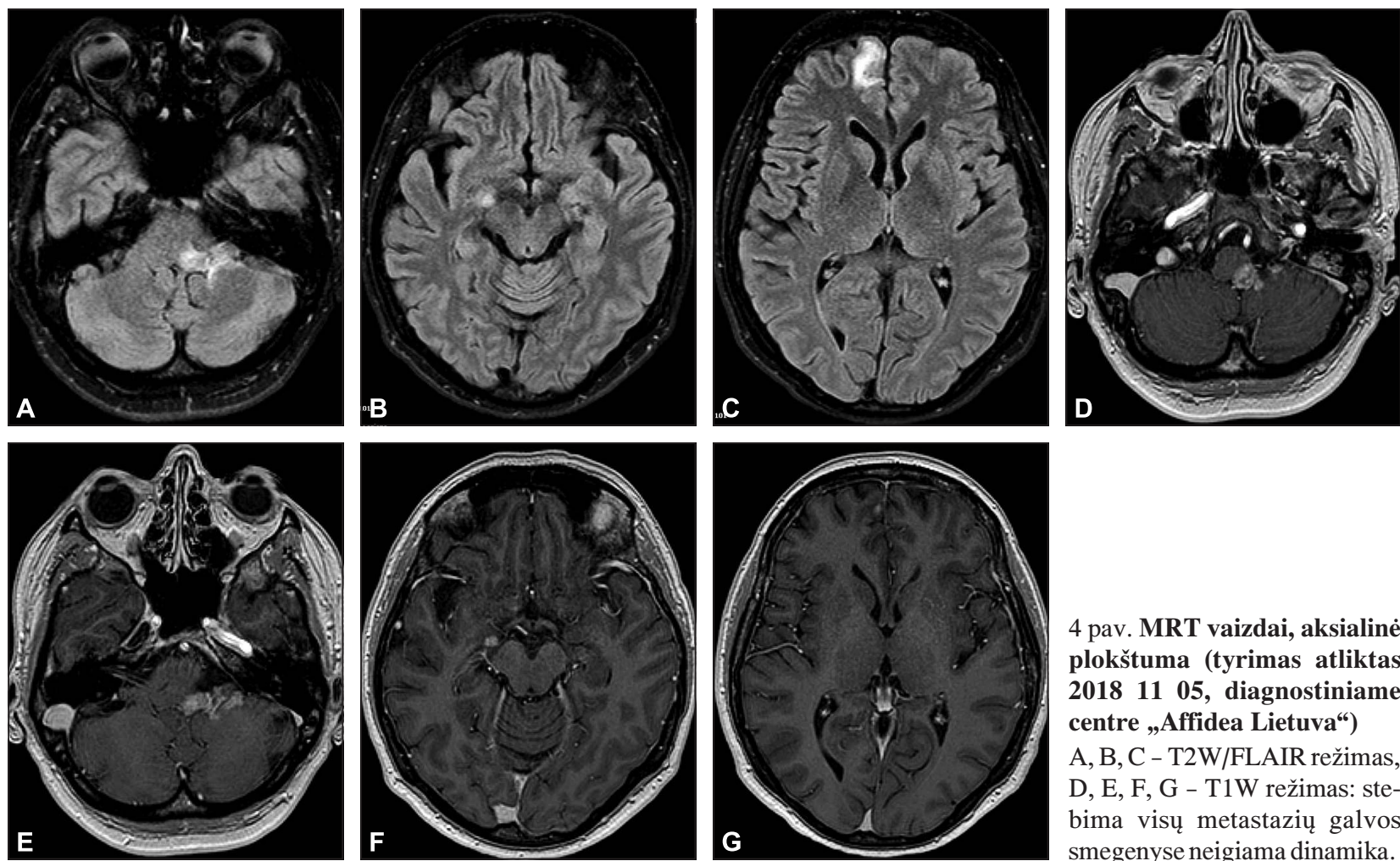

4 pav. MRT vaizdai, aksialinė plokštuma (tyrimas atliktas 20181105 , diagnostiniame centre „Affidea Lietuva“)

A, B, C - T2W/FLAIR režimas, $\mathrm{D}, \mathrm{E}, \mathrm{F}, \mathrm{G}-\mathrm{T} 1 \mathrm{~W}$ režimas: stebima visų metastazių galvos smegenyse neigiama dinamika.

Metus po taikyto gydymo pacientès būklè išliko stabili; toliau tęstas chemoterapinis gydymas; pakartotiniuose tyrimuose neigiamos dinamikos nestebèta. Praejus beveik dvejiems metams nuo SRS gydymo, pacientę

pradejo varginti silpnumas, nerimas, galvos svaigimas, tremoras, sunkumas ryti. Stebint neigiamą radiologinę metastazių galvos smegenyse dinamiką (4 pav., 201811 05), t. y. išryškejjus naujam patologiniam kon-
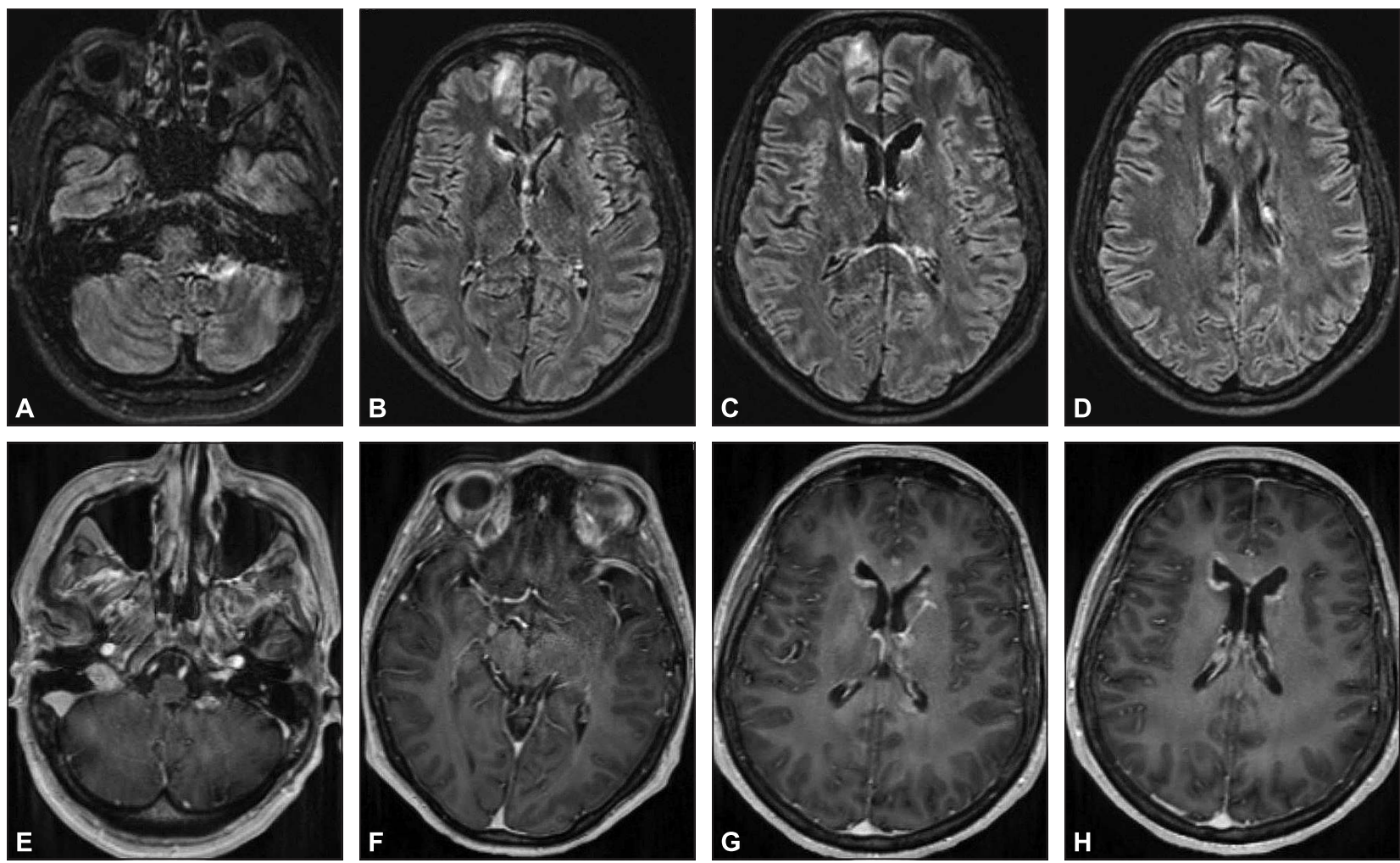

5 pav. MRT vaizdai, aksialinė plokštuma (tyrimas atliktas LSMU KK Radiologijos klinikoje, 201909 24)

A, B, C, D - T2W/FLAIR režimas, E, F, G, H - T1W režimas: stebima neigiama dinamika: išryškėjo intraventrikulinès metastazės frontaliniuose raguose, skilvelių kūnuose; parenchiminių židinių dinamika stabili 
Lentelè. Krūties vèžio metastazių lokalizacija ir dažniausiai sukeliami simptomai [9]

\begin{tabular}{|l|l||}
\hline \hline Metastazių vieta & Sukeliami simptomai \\
\hline Bet kurios lokalizacijos & Nuovargis, miego sutrikimai, depresija \\
\hline Kaulai & Skausmas, hiperkalcemija, patologiniai lūžiai, judrumo praradimas \\
\hline $\begin{array}{l}\text { Centrinė nervų sistema } \\
\text { (priklausomai nuo lokalizacijos) }\end{array}$ & $\begin{array}{l}\text { Galvos skausmas, sumišimas, silpnumas, skausmas, traukuliai, pakitęs mąstymas, galvinių } \\
\text { nervų paralyžius, kalbos sutrikimai, pykinimas, vėmimas, hemiparezė ir regejimo sutrikimai }\end{array}$ \\
\hline Oda & Skausmas, infekcija, kraujavimas \\
\hline $\begin{array}{l}\text { Skrandis ir žarnynas (kepenys, } \\
\text { ascitas, pilvaplèvė ir kiti) }\end{array}$ & $\begin{array}{l}\text { Skausmas, pykinimas, vėmimas, viduriavimas, ankstyvas sotumo jausmas, apetito } \\
\text { praradimas, dusulys (dėl ascito), gelta, kraujavimas }\end{array}$ \\
\hline Plaučiai & Skausmas, dusulys, kraujo atkosėjimas, kosulys \\
\hline Limfmazgiai & Petinio rezginio neuropatija, skausmas \\
\hline
\end{tabular}

trastinę medžiagą $(\mathrm{k} / \mathrm{m})$ kaupiančiam židiniui dešinėje uncus projekcijoje ir padidejjus $\mathrm{k} / \mathrm{m}$ kaupiantiems židiniams užpakalinėje dauboje kairẻje bei dešinėje frontalinèje skiltyje, pacientė nusprendè antrą kartą kreiptis ị kliniką „Sigulda“ Latvijoje. Gydymas „CyberKnife“ aparatu buvo veiksmingas ir antrą kartą radiologiškai stebèta teigiama dinamika, susilpnejjo pacientès jaučiami simptomai.

Tačiau praejjus dar 9 mèn. po antrojo gydymo, SRS atliktoje galvos smegenų MRT (5 pav., 20190924 ) stebimas intraventrikulinis vėžio plitimas, kuris ryškiai pablogino klinikinę pacientès būklę.

\section{APTARIMAS}

\section{Plitimas}

Pastebèta, kad CNS metastazių rizika yra susijusi su keliais faktoriais: krūties vėžio molekuliniu-histologiniu ti$\mathrm{pu}$, specifinemis pirminio naviko savybėmis, pacientès menopauziniu statusu ir amžiumi. Didžiausią riziką, kad liga per 10 metų išplis ị smegenis, turi moterys, sergančios liuminaliniu B ir HER2 pozityviu krūties vèžiu (po $12 \%$ ). Mažesnė rizika yra sergant liuminaliniu-HER2 pozityviu $(8 \%)$ ir trigubai negatyviu (7\%) vėžiu. Rečiausiai i smegenis išplinta liuminalinio A subtipo krūties vèžys $(0,7 \%)$ [7]. CNS metastazių rizika yra didesnè, esant ligos išplitimui daugiau nei 4 limfmazgiuose, naviko diferenciacijos (G) laipsniui - 3-4, pirminio naviko dydžiui $>2 \mathrm{~cm}$. Pacientès, kurios dar nepatyrè menopauzès, turi didesnę CNS metastazių riziką. Ši rizika yra ypač didelė moterims, kurios krūties vėžiu susirgo iki $35 \mathrm{~m}$. amžiaus [8]. Iš minètų su ligos išplitimu ị CNS susijusių faktorių mūsų aptartu atveju matome šiuos: jaunas pacientès amžius (diagnozės nustatymo metu pacientei buvo $35 \mathrm{~m}$.); liuminalinis-HER2 pozityvus vèžio subtipas; ligos išplitimas ị sritinius limfmazgius (tikslus skaičius nežinomas); pirminio naviko dydis - $>2 \mathrm{~cm}$. Svarbu atkreipti demesi, kad krūties vėžio metastazès gali plisti ne tik ị smegenų parenchimą, bet ir intraventrikuliariai bei leptomeningialiai [6].

\section{Klinikiniai požymiai}

Metastazinis krūties vėžys (MKV) gali pasireikšti skirtingais simptomais, kurie yra bendrieji arba susiję su metastazių lokalizacija (lentelè) [9].

Išsami literatūros apžvalga parodè, kad pacientų, turinčių krūties věžio metastazių CNS, dažniausiai patiriami simptomai yra pykinimas (49\%), galvos skausmas (35\%), hemiparezè (22\%), regèjimo sutrikimai (13\%), traukuliai (12\%) [10]. Naujai atsiradę neurologiniai simptomai ne visada žymi ligos išplitimą i CNS, tačiau daugiau nei vieno neurologinio simptomo buvimas koreliuoja su didesne CNS metastazių rizika [11]. Mūsų aptartu atveju, praejus 7 mėnesiams nuo krūties véžio diagnozės, pacientę staiga pradejjo varginti trys nauji neurologinio pobūdžio simptomai, todèl, kaip ir rekomenduojama literatūroje, buvo atlikti tyrimai ligos išplitimui ị CNS ịvertinti.

\section{Diagnostika}

Didejjant radiologinių diagnostikos metodu jautrumui ir tobulèjant sisteminiam vėžio gydymui, lemiančiam ilgèjantị pacientų išgyvenamumą, metastazès CNS nustatomos vis dažniau [12].

Kai kurių organų piktybinių navikų metastazès pasižymi skirtingomis plitimo ị CNS tendencijomis, tačiau, deja, šios tendencijos nèra specifinès. Norime atkreipti dèmesị $i$ literatūroje minimus krūties vėžio metastazèms smegenyse būdingus radiologinius požymius:

1. Metastazių kiekis. Priešingai nei plaučių vėžiui ar melanomai, kuriems būdingos daugybinès CNS metastazės, krūties, inkstų, storosios žarnos ir skydliaukès vèžiui būdingos pavienès metastazès [13].

2. Lokalizacija. Būdingiausia ịvairios kilmès CNS metastazių vieta yra smegenų pusrutuliai, baltosios ir pilkosios medžiagų jungtis [14-17]. Tačiau krūties véžio metastazès dažniausiai aptinkamos smegenèlèse bei pamato branduoliuose $[10,16,18,19]$. Vienoje iš minètų lokalizacijų - smegenèlėse - metastazinis židinys buvo nustatytas ir mūsu aptartai pacientei. Galimas ir leptomeninginis plitimas CNS, kaip ir mūsų analizuotu klinikiniu atveju, tačiau tai yra gana reta ir mažai literatūroje išanalizuota krūties vèžio metastazių lokalizacija [6]. 
3. Kraujavimas. Dalis CNS metastazių yra linkusios pakraujuoti, pvz., metastazès iš melanomos, inkstų ląstelių karcinomos, skydliaukès vėžio, choriokarcinomos. Tačiau iš visų hemoraginių metastazių plaučių ir krūties vėžys yra dažniausios etiologijos dèl didelio jų paplitimo [13].

4. Išvaizda. Krūties vėžio CNS metastazès KT be kontrastavimo vaizduose dažniausiai matomos kaip pavieniai mazgai, kurie gali būti įvairaus tankumo (izo-, hipo- ar hiperintensiniai) ir dažnai yra supami vazogeninès edemos zonos. Po kontrastavimo metastazių $\mathrm{k} / \mathrm{m}$ kaupimas taip pat yra ịvairus ir gali būti intensyvus, punkcinis, mazginis ar žiedinis [14]. CNS metastaziniai židiniai MRT T1 sekos vaizduose dažniausiai yra izo- ar hipointensiniai, o T2 sekos vaizduose - hiperintensiniai [14, 15], tačiau pakraujavimas metastazèje gali pakeisti signalo intensyvumą [14]. Metastazes supanti edemos zona neretai yra neproporcingai didelè, lyginant su židinio dydžiu [15]. Net skirtingi to paties vėžio potipiai gali turèti skirtingą vaizdą, pvz., CNS metastazès iš trigubai neigiamo krūties vėžio paprastai primena cistinę nekrozę (turi ploną sienelę su centrine nekroze), palyginti su kitais krūties vėžio potipiais [20].

Diagnozuojant metastazinę CNS ligą, pirmiausia svarbu paneigti kitas būkles, galinčias mimikuoti metastazes, t. y. pirminiai smegenų augliai, infekciniai procesai, progresuojanti daugiažidininė leukoencefalopatija, demielinizacija, paraneoplastiniai sindromai, infarktas ar kraujavimas i smegenis bei jatrogeniniai padariniai, pvz., spindulinès ligos sukelta nekrozė [17]. Iprastai KT be kontrastavimo yra pirmasis radiologinis tyrimas, atliekamas pacientams, kuriems pasireišké neurologiné simptomatika, nes jo metu galima greitai atmesti gyvybei pavojingas patologijas, pvz., kraujavimą, hidrocefaliją bei didelès apimties masès efektą [13]. MRT su kontrastavimu yra informatyviausias tyrimo metodas, pasižymintis didesniu jautrumu nei KT ir MRT be kontrastavimo, tiek aptinkant darinius smegenyse, tiek diferencijuojant metastazes nuo kitų centrinès nervų sistemos pažeidimų [17]. Taip pat MRT su kontrastavimu yra patikimas metodas, diagnozuojant ir leptomeningines metastazes [6]. Kaip ir teigiama literatūroje, mūsų aptariamu atveju pirmiausia, siekiant paneigti ūmias gyvybei pavojingas patologijas, buvo atlikta KT, o vèliau metastazinio krūties vėžio CNS diagnozė patvirtinta atlikus MRT. Kitos pažangios technologijos, pvz., MR spektroskopija, MR perfuzija, difuziniai tyrimai (DWI, DTI), gali būti vertingos diferencijuojant metastazes smegenyse nuo kitos kilmès patologijų ir stebint atsaką i gydymą [13]. Esant abejonių, ar matomi dariniai yra metastazės, ypač kai aptinkamas tik vienas darinys, tikslinga atlikti židinio biopsiją [17].

\section{Gydymas}

Svarbu paminėti, kad klinikinių simptomų kontrolè yra ypač reikšminga pacientams su metastazėmis smegenyse. Tai susideda iš: peritumorinės edemos, padidejusio intrak- ranijinio slègio kontrolès ir venų tromboembolinès ligos valdymo bei prevencijos [7].

Sprendžiant, kurị ar kuriuos iš galimų CNS metastazių gydymo metodų (chirurginė rezekcija, stereotaksinė radiochirurgija (SRS) ar visų smegenų spindulinė terapija (WBRT)) pasirinkti, atsižvelgiama į metastazių kiekį, jų operabilumą, paciento būklę ir gydymo taktikų prieinamumą. Dažniausiai, esant tik vienai ar kelioms operabilioms metastazèms, pirmenybè teikiama chirurginei rezekcijai [7,21]. Tačiau tyrimai parodè, kad, taikant tik chirurginę smegenų metastazių rezekciją, ilgalaikè vietinė kontrolè nėra pakankamai užtikrinama, o vietinè naviko pasikartojimo rizika labiausiai sumažinama, kai rezekcijos zonoje yra taikoma SRS [22]. Jei rezekcija techniškai neịmanoma dèl židinių lokalizacijos ar paciento būklès, rekomenduojama taikyti vien SRS [7, 21, 23]. Ilgą laiką i tradicinị pacientų, turinčių CNS metastazių, gydymo planą įejo WBRT (kaip savarankiškas gydymo metodas ar suderintas su rezekcija ar SRS). Teigiama, kad šalia lokalaus metastaziu gydymo (rezekcija, SRS ar rezekcija + SRS) taikant WBRT, intrakranijinė židinių kontrolè pagerejja, tačiau tai reikšmingos įtakos bendram išgyvenamumui neturi [18, 24-27]. Be to, literatūroje vis daugeja duomenų apie lokalaus gydymo pranašumą prieš WBRT, gydant limituotą CNS metastazių kieki, dèl geresnių kognityvinių gebejjimų rezultatų ir palankesnès su sveikata susijusios gyvenimo kokybės [24-26, 28]. Pacientams, turintiems daugybinių didelių ar difuzinių metastazių, taip pat ir tiems, kurių prognozė yra bloga (bloga būklè ar greitai progresuojanti sisteminè liga), rekomenduojama atlikti WBRT. SRS gali būti pridedama po WBRT pacientams, kurių prognozė yra gera ir likusių židinių skaičius yra ribotas $[7,29]$.

\section{Prognozè}

Apskritai yra stebimas MKV išgyvenamumo ilgėjimas, tiek tarp de novo ir pasikartojančio $\mathrm{MKV}$, tiek ir skirtinguose ER potipiuose [30]. Tarpusavyje lyginant atokiųju krūties vėžio metastazių vietas, blogiausia prognozė yra pacientų, kuriems pirmosios tolimosios metastazès atsirado CNS [5]. Išsami apžvalga, apimanti 35 metų literatūrą apie krūties vėži ir jo plitimą ị CNS, nustatè, kad su ilgesniu išgyvenamumu koreliuoja šie faktoriai: tik vienos metastazès buvimas, metastazių dydis $-\leq 5 \mathrm{~cm}$, ekstrakranijinių metastazių nebuvimas, Karnofskio indeksas $->70$ ir trigubai neigiamo molekulinio-histologinio vėžio tipo nebuvimas [10] (pastarasis asocijuojamas su ankstyvomis tolimosiomis metastazėmis ir bloga prognoze). Vidutinis laiko intervalas nuo krūties vėžio diagnozès iki smegenų metastazių nustatymo yra 34 mėnesiai, o nuo smegenų metastazių nustatymo iki mirties - 15 mėnesių [10]. Esant leptomeninginėms metastazėms, išgyvenamumas labai sumažèja ir vidutiniškai siekia iki 6 mènesių [6]. Mūsų analizuotu klinikiniu atveju, ligos išplitimas į CNS buvo nustatytas nebūdingai anksti - vos po 7 mèn. nuo krūties vẻžio diagnozès, taip pat pacientei buvo stebètas leptomeninginis ligos išplitimas. 


\section{„CyberKnife“ procedūra}

„CyberKnife“ yra fotonų pagrindu veikianti SRS sistema, kuri pasižymi didele judesių amplitude ir tikslumu. „CyberKnife“ procedūros metu ị taikinị galima nukreipti labai didelę skirtingų krypčių jonizuojančios spinduliuotès dozę, tačiau taip kuo mažiau pažeidžiant aplink esančius sveikus audinius ir struktūras. Be to, ši technologija leidžia realiu laiku stebėti darinius, įveikti kvėpavimo judesių sukeliamus poslinkius ir taip dar labiau apsaugo sveikus audinius. „CyberKnife“ gali būti naudojama gydant gerybinius ir piktybinius navikus bei metastazes, ypač esančias šalia gyvybiškai svarbių organų ir kritinių struktūrų (pvz., regos, klausos, veidinio nervų; smegenų kamieno, nugaros smegenų ir kt.), ir kitas ịvairias kūno dalių malformacijas [30, 31].

\section{IŠVADOS}

Centrinė nervų sistema, kaip pirmųjų tolimụjų krūties vèžio metastazių atsiradimo vieta, yra siejama su blogiausia ligos prognoze. Klinikinė metastazių CNS išraiška gali labai varijuoti. Krūties věžiu sergantys pacientai, kuriems pasireiškė neurologinė simptomatika, turètų būti ištirti dẻl galimo ligos išplitimo ị centrinę nervų sistemą. Jautriausias tyrimas, diagnozuojant metastazes smegenyse, yra magnetinio rezonanso tomografija su kontrastavimu. Yra galimi keli skirtingi metastazių centrinejje nervų sistemoje gydymo metodai, i̇skaitant chirurgiją, SRS ir WBRT. Literatūroje daugejja duomenų apie lokalaus gydymo pranašumą prieš WBRT, gydant limituotą CNS metastazių kiekị, dèl geresnių kognityvinių gebẻjimų rezultatų ir palankesnės su sveikata susijusios gyvenimo kokybės. Kiekvienam pacientui turètų būti sudaromas individualus gydymo planas, atsižvelgiant ị konkrečią klinikinę situaciją ir gydymo taktikų prieinamumą.

\section{Literatura}

1. World Health Organization, The Global Cancer Observatory. Fact Sheet: Breast, Globocan 2018. 03-2019. https://gco.iarc.fr/today/data/factsheets/cancers/20-Breastfact-sheet.pdf

2. World Health Organization, The Global Cancer Observatory. Cancer tomorrow [Internet]. 2019. https://gco.iarc.fr/ tomorrow/graphic-isotype?type $=0 \&$ type_sex $=0 \&$ mode $=$ population $\&$ sex $=2 \&$ populations $=900 \&$ cancers $=20 \&$ age group $=$ value \&apc_male $=0 \& a p c \_f e m a l e=0 \&$ single_unit $=$ $100000 \&$ print $=0$

3. World Health Organization, The Global Cancer Observatory. Fact Sheet: Lithuania, Globocan 2018. 05-2019. https://gco.iarc.fr/today/data/factsheets/populations/ 440-lithuania-fact-sheets.pdf

4. Berman AT, Thukral AD, Hwang W, Solin LJ, Vapiwala N. Incidence and patterns of distant metastases for patients with early-stage breast cancer after breast conservation treatment. Clin Breast Cancer 2013; 13(2): 88-94. https://doi.org/ 10.1016/j.clbc.2012.11.001
5. Gerratana L, Fanotto V, Bonotto M, Bolzonello S, Minisini AM, Fasola G, et al. Pattern of metastasis and outcome in patients with breast cancer. Clin Exp Metastasis 2015; 32: 125-33. https://doi.org/10.1007/s10585-0159697-2

6. Scott BJ, Kesari S. Leptomeningeal metastases in breast cancer. Am J Cancer Res 2013; 3(2): 117-26.

7. Lin NU, Ramakrishna N. Management of brain metastases in breast cancer [Internet]. UpToDate. Updated: Apr 18, 2019. https://www.uptodate.com/contents/management-of-brainmetastases-in-breast-cancer

8. Polivka J Jr, Kralickova M, Polivka J, Kaiser C, Kuhn W, Golubnitschaja O. Mystery of the brain metastatic disease in breast cancer patients: improved patient stratification, disease prediction and targeted prevention on the horizon? EPMA J 2017; 8(2): 119-27. https://doi.org/10.1007/ s13167-017-0087-5

9. Irvin W Jr, Muss HB, Mayer DK. Symptom management in metastatic breast cancer. Oncologist 2011; 16(9): 1203-14. https://doi.org/10.1634/theoncologist.2011-0159

10. Rostami R, Mittal S, Rostami P, Tavassoli F, Jabbari B. Brain metastasis in breast cancer: a comprehensive literature review. J Neurooncol 2016; 127: 407-14. https://doi.org/ 10.1007/s11060-016-2075-3

11. Cacho-Díaz B, Spínola-Maroño H, Arrieta VA, GranadosGarcía M, Wegman-Ostrosky T, Mendoza-Olivas LG, et al. Diagnosis of brain metastases in breast cancer patients resulting from neurological symptoms. Clin Neurol Neurosurg 2018; 173: 61-4. https://doi.org/10.1016/j.clineuro. 2018.08.002

12. Amsbaugh MJ, Kim CS. Cancer, Brain Metastasis. [Updated 2019 Aug 30]. In: StatPearls [Internet]. Treasure Island (FL): StatPearls Publishing; 2020 Jan-. Available from: https://www.ncbi.nlm.nih.gov/books/NBK470246/

13. Fink KR, Fink JR. Imaging of brain metastases. Surg Neurol Int 2013; 4(Suppl 4): S209-19. https://doi.org/10.4103/ 2152-7806.111298

14. El-Feky M, Orton T, et al. Brain metastases [Internet]. Radiopaedia. Available from: https://radiopaedia.org/ articles/brain-metastases

15. Grand S, Pasteris C, Attye A, Le Bas JF, Krainik A. The different faces of central nervous system metastases. Diagn Interv Imaging 2014; 95(10): 917-31. https://doi.org/ 10.1016/j.diii.2014.06.014

16. Quattrocchi CC, Errante Y, Gaudino C, Mallio CA, Giona A, Santini D, et al. Spatial brain distribution of intra-axial metastatic lesions in breast and lung cancer patients. J Neurooncol Neurosurgery 2012; 110: 79-87. https://doi.org/10.1007/ s11060-012-0937-x

17. Loeffler JS. Epidemiology, clinical manifestations, and diagnosis of brain metastases [Internet]. UpToDate. Updated: Jul 13, 2018. https://www.uptodate.com/contents/ epidemiology-clinical-manifestations-and-diagnosis-ofbrain-metastases

18. Bender ET, Tomé WA. Distribution of brain metastases: implications for non-uniform dose prescriptions. Br J Radiol 2011; 84(1003): 649-58. https://doi.org/10.1259/bjr/ 30173406

19. Graf AH, Buchberger W, Langmayr H, Schmid KW. Site preference of metastatic tumours of the brain. Virchows Arch A Pathol Anat 1988; 412(5): 493-8. https://doi.org/10.1007/ BF00750584

20. Yeh RH, Yu JC, Chu CH, Ho CL, Kao HW, Liao GS, et al. Distinct MR imaging features of triple-negative breast can- 
cer with brain metastasis. J Neuroimaging 2015; 25(3): 474-81. https://doi.org/10.1111/jon. 12149

21. Loeffler JS. Overview of the treatment of brain metastases [Internet]. UpToDate. Updated: Mar 20, 2020. https://www.uptodate.com/contents/overview-of-thetreatment-of-brain-metastases

22. Mahajan A, Ahmed S, McAleer MF, Weinberg JS, Li J, Brown $\mathrm{P}$, et al. Post-operative stereotactic radiosurgery versus observation for completely resected brain metastases. Lancet Oncol 2017; 18(8): 1040-8. https://doi.org/10.1016/ S1470-2045(17)30414-X

23. Trifiletti DM, Lee CC, Kano H, Cohen J, Jonopaul-Naylor J, Alonso-Basanta $\mathrm{M}$, et al. Stereotactic radiosurgery for brainstem metastases: an international cooperative study to define response and toxicity. Int J Radiat Oncol Biol Phys 2016; 96(2): 280-8. https://doi.org/10.1016/j.ijrobp. 2016.06.009

24. Brown PD, Ballman KV, Cerhan JH, Anderson SK, Carrero XW, Whitton AC, et al. Postoperative stereotactic radiosurgery compared with whole brain radiotherapy for resected metastatic brain disease (NCCTG N107C/CEC.3): a multicentre, randomised, controlled, phase 3 trial. Lancet Oncol 2017; 18(8): 1049-60. https://doi.org/10.1016/ S1470-2045(17)30441-2

25. Brown PD, Jaeckle K, Ballman KV, Farace E, Cerhan JH, Anderson SK, et al. Effect of radiosurgery alone vs radiosurgery with whole brain radiation therapy on cognitive function in patients with 1 to 3 brain metastases: a randomized clinical trial. JAMA 2016; 316(4): 401-9. https://doi.org/10.1001/jama.2016.9839

26. Tsao MN, Xu W, Wong RKS, Lloyd N, Laperriere N, Sahgal A, et al. Whole brain radiotherapy for the treatment of newly diagnosed multiple brain metastases. Cochrane Database Syst Rev 2018; (1): CD003869. https://doi.org/ 10.1002/14651858.CD003869.pub4

27. Soon YY, Tham IWK, Lim KH, Koh WY, Lu JJ. Surgery or radiosurgery plus whole brain radiotherapy versus surgery or radiosurgery alone for brain metastases. Cochrane Database Syst Rev 2014; (3): CD009454. https://doi.org/10.1002/ 14651858.CD009454.pub2

28. Soffietti R, Kocher M, Abacioglu UM, Villa S, Fauchon F, Baumert BG, et al. A European Organisation for Research and Treatment of Cancer Phase III Trial of adjuvant whole-brain radiotherapy versus observation in patients with one to three brain metastases from solid tumors after surgical resection or radiosurgery: quality-of-life results. J Clin Oncol 2013; 31(1): 65-72. https://doi.org/10.1200/JCO. 2011.41.0639

29. Shinde A, Akhavan D, Sedrak M, Glaser S, Amini A. Shifting paradigms: whole brain radiation therapy versus stereotactic radiosurgery for brain metastases. CNS Oncol 2019; 8(1): CNS27. https://doi.org/10.2217/cns-2018-0016

30. Caswell-Jin JL, Plevritis SK, Tian L, Cadham CJ, Xu C, Stout NK, et al. Change in survival in metastatic breast cancer with treatment advances: meta-analysis and systematic review. JNCI Cancer Spectr 2018; 2(4): pky062. https://doi.org/10.1093/jncics/pky062

31. Oncolink team. Radiation therapy: which type is right for me? [Internet]. OncoLink. Last Reviewed: March 3, 2020 https://www.oncolink.org/cancer-treatment/radiation/ introduction-to-radiation-therapy/radiation-therapy-whichtype-is-right-for-me

\section{Radzevičiūtè, R. Pačinskaitė, R. Gleiznienė}

\section{BREAST CANCER METASTASES IN CENTRAL NERVOUS SYSTEM. CASE REPORT AND REVIEW OF LITERATURE}

\section{Summary}

Breast cancer is the most frequently diagnosed cancer among women worldwide. The most common first site of distant spread is bone, followed by lung, brain, and liver. Symptoms of metastatic breast cancer can vary greatly depending on the location of the metastases. Symptoms of metastases of breast cancer in the brain, depending on location, can include nausea, headache, hemiparesis, blurred vision, seizures, slurred speech, impaired thinking, dizziness. Breast carcinoma tends to metastasize to the cerebellum and the basal ganglia. A very aggressive intraventricular, leptomeningeal spread to the central nervous system is also possible; however, it is a rare localization of breast cancer metastasis. Magnetic resonance imaging (MRI) is the most sensitive diagnostic tool for the detection of brain metastases. Treatment approaches of brain metastases include surgery, stereotactic radiosurgery (SRS), and whole brain radiation therapy (WBRT). In this article we present a case of a 34-year-old woman with a clinical diagnosis of breast cancer and metastases to the central nervous system. The patient received treatment at the stereotactic radiosurgery centre Sigulda in Latvia; during the course of the disease, intraventricular metastatic spread to the brain was diagnosed. In addition, the article also reviews the literature on the clinical presentation of intracerebral breast cancer metastases, diagnosis, and treatment recommendations.

Keywords: breast cancer, brain metastases, magnetic resonance imaging, intraventricular spread, leptomeningeal spread, stereotactic radiosurgery.

Gauta:

Priimta spaudai:

20200401 20200403 